Vol. 7, No. 1, 2020

https://doi.org/10.23939/eem2020.01.075

UDC 658:338: 65.012.8

JEL Classification Code: M 41

O. Grytsay
Lviv Polytechnic National University, Ukraine, PhD, Associate Professor
e-mail: olga.i.grytsay@1pnu.ua
ORCID: 0000-0001-6305-9219

M. Havran

Lviv Polytechnic National University, Ukraine, PhD, Associate Professor

e-mail: mario_g@ukr.net

ORCID: 0000-0003-1345-9235

\title{
ACCOUNTING AND ANALYTICAL SUPPORT FOR FORMATION OF ENTERPRISE ECONOMIC SECURITY COSTS AND THEIR CONTROLLING PROCESS
}

\begin{abstract}
The article reveals the interdependence of enterprise property preservation and quality of information for ensuring management and controlling processes efficiency. The dependence of economic security on qualitatively-formed accounting and analytical support for such purposes is substantiated. It is analyzed the enterprise's activities in terms of economic security formation by rational costs, in particular the influence of spent financial resources on employees' physical and moral security, formation of intellectual property, etc. The authors prove that nowadays, there are inconsistencies of the current accounting with the enterprise economic security requirements. The scientific validity of this study is to overcome the inconsistency of different user groups' information needs with appropriate accounting data that causes difficulties to make timely and reasonable management decisions. It is emphasized that there are no methodological recommendations for reflecting enterprise economic security costs in its accounting. The novelty of the research paper is to partially solve the outlined problems because of using a subaccount "Economic security costs" in accounting. The authors argue that this additional methodical measure will help to find necessary data and use information more quickly for managing economic security costs. Considering no imperative restrictions on creating separate articles in
\end{abstract}

reports for these types of costs, the authors suggest internal management accounting report forms. Their usage will create the environment of whole information about enterprise economic security costs for conducting analysis and maintaining control in this field. Some forms are proposed to be used in internal management reporting system ("Consolidated statement of enterprise economic security costs accounting" and "Statement of analytical accounting of the enterprise economic security costs"). The suggested form "Control statement of economic security costs by articles" allows a more detailed study of costs deviations from the planned or allowable amounts in terms of economic security costs. As internal control is a measure it is possible to verify the expediency, efficiency or legitimacy of business operations associated with enterprise economic security. For conducting the research, general scientific methods, special approaches in the subject area of knowledge and comparative analysis means have been applied.

Key words: enterprise economic security costs, management, accounting and analytical system, reporting, control.

\section{Problem statement}

Today, there are inconsistencies of the current accounting with the enterprise economic security requirements, because the different user 
groups' information needs are not satisfied with appropriate accounting data. In addition, there are no methodological recommendations for reflecting enterprise economic security costs and no internal management accounting report forms, which would systematize information for operational management and maintaining costs control.

A properly formed accounting and analytical subsystem of the enterprise will help to anticipate and avoid problems that affect the enterprise economic security, as well as to adjust its operations.

\section{Analysis of recent research and publications}

Some aspects of the enterprise economic security are considered in [1], [2], [3]. The expediency of providing users with relevant accounting information has been proved in [4] and [5], and the need for its documentary confirmation has been demonstrated in [6]. The issues of organizing and methods for controlling economic activity costs in the field of enterprise economic security costs were raised in [7], [8] [9]; the problem of accounting for the enterprise economic security costs was firstly mentioned in [2] and [9]. But these issues have not been sufficiently resolved yet. As result, they require further investigations.

\section{Goals statement}

The aim of our research is to give the definition of the term "enterprise economic security costs", analyze information about these costs in the accounting and enterprise statements, and study peculiarities of the process of controlling these costs.

\section{Results}

\section{The concepts of economic security} and enterprise economic security costs

Theorists and practitioners have recently paid more attention to economic security, as a subject of economic science research, because growing competition emphasizes the need for protecting economic interests. Due to economic security an enterprise can respond to external and internal impact factors in time. It does not only ensure the economic stability of the enterprise but also helps to improve its employees' well-being level.

The interpretation of the economic security system is given in [1], as an organizational complex, which forms a set of measures for organizing, management, technical and legitimate support aimed at fulfilling interests of enterprise management and investors for security and stimulating enterprise sustainable development.

In order to realize these functions and fulfil the challenges that the economic security system faces with, it is important to identify necessary means and resources for this. The enterprise economic security system performance and viability depend entirely on the coherence and systematic functioning of the interaction mechanism of all elements in the enterprise economic security system. The economic security system with a well-organized cost base of the enterprise is known to be effective.

Despite the fact that economic security costs management is one of the important elements of the enterprise operations, this type of costs is not distinguished in the regulatory base. We should consider the term "economic security costs" as an aggregate of all resources increasing enterprise liabilities and further bringing economic benefits in the form of an efficient operation of the enterprise security service.

National accounting principles (standard) (NAP(S)) 16 "Costs" [10] shall distinguish several articles which would partially reflect the economic security costs. For example, there are safety costs that are included in representative, total production and total economic costs referring to administrative costs, or the costs of non-current assets protection related to sales, which are part of the costs of sales.

We distinguish the following approaches to defining enterprise economic security costs, such as: organizational, functional and managerial. An organizational approach is mainly used in management accounting and mostly allows specifying costs by assigning them to the appropriate economic security services of the business entity. A functional and managerial approach is used in accounting, on which basis 
costs are determined by a set of costs that are associated with the performance of individual functions. In general, enterprise security is possible due to the effectively arranged accounting and analytical system, which will help the enterprise to identify its problems, risks and operational threats, as well as to prevent the negative impact of internal and external factors, which are presented in Fig. 1.

\begin{tabular}{|c|c|c|c|c|}
\hline \multirow{2}{*}{$\begin{array}{l}\text { Enterprise } \\
\text { organizational } \\
\text { structure }\end{array}$} & \multirow{5}{*}{ 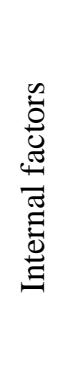 } & \multirow{4}{*}{$\begin{array}{l}\text { Enterprise economic } \\
\text { security }\end{array}$} & \multirow{5}{*}{ 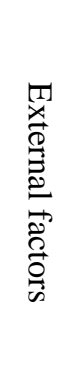 } & Competitors \\
\hline & & & & Suppliers \\
\hline \multirow{2}{*}{$\begin{array}{l}\text { Human resources, } \\
\text { labour productivity }\end{array}$} & & & & Legislative changes \\
\hline & & & & $\begin{array}{l}\text { Changing market } \\
\text { conditions }\end{array}$ \\
\hline Enterprise strategy & & & & Demand \\
\hline
\end{tabular}

Fig. 1. Factors affecting economic security*

* Source: [3]

Therefore, we suggest considering the enterprise economic security as such its condition that will provide opportunities for preserving enterprise's interests before internal and external threatening factors, ensuring its sustainable development, achieving its mission and goals, and maximizing profits. At the same time, we define "economic security costs" as a disposal of assets or increasing entity's liabilities that are arising for preserving its interests in the context of internal and external threatening factors, ensuring its sustainable development, realizing its mission and goals, and maximizing profits.

\section{Accounting and analytical reflection of information on economic security costs}

The functioning of the enterprise economic security system depends on the quality, completeness, reliability and timeliness of the information generating by the enterprise itself and coming outside. Quality information can be generated only due to the interconnection of the accounting department with other enterprise's structural units. Costs spent on such security formation and management is an important part in accounting and analytical information on the enterprise economic security. Studying of the role of costs in enterprise economic security management may have a sufficiently branched network of directions [1].

In accounting, the basis for formation of the costs associated with a particular activity is grounded on a functional approach, which involves the attribution of costs to one type or another, depending on the areas of activities - production or non-production. Such approach is not reasonable enough in terms of economic security costs. For example, according to accounting legislation rules, employee safety costs are shown in the account 91 "Total production costs" and are considered to be production costs, i.e. they relate to all enterprise personnel, including those involved in the nonproduction area. However, according to the instructions in the accounting plan, total production costs relate to supporting production activities, and in this case, their content does not quite correspond to their economic nature. Considering costs on physical protection of fixed assets and other tangible fixed assets that cause enterprise products sales, we understand that ensuring of their preservation applies to all areas of the enterprise activities, not just product sales related activities. In the accounting system, the costs are distinguished as costs included in the cost of production (production costs), and costs financed by profit (non-production costs). Using these rules, occupational safety and health costs shall be written off to the cost of production, and representative costs shall be offset by profit. Therefore, economic security costs can be classified as internal organizational and transactional ones. It is worth finding out what costs should be included in a particular classification group. The classification of enterprise economic security costs is illustrated in Table 1. 
Classification of enterprise economic security costs

\begin{tabular}{|l|l|l|}
\hline \multicolumn{1}{|c|}{$\begin{array}{c}\text { Distinguished } \\
\text { feature }\end{array}$} & \multicolumn{1}{|c|}{ Internal organizational } & \multicolumn{1}{c|}{ Transactional } \\
\hline Notion & $\begin{array}{l}\text { caused by ensuring control and distribution of resources } \\
\text { within the enterprise }\end{array}$ & $\begin{array}{l}\text { related to minimizing the opportunistic } \\
\text { behavior of external counterparts that } \\
\text { requires additional information resources } \\
\text { while choosing relationships with them }\end{array}$ \\
\hline $\begin{array}{l}\text { Reflection in } \\
\text { financial } \\
\text { statements }\end{array}$ & reflected in financial statements as operating expenses & mostly are not legally regulated \\
\hline $\begin{array}{l}\text { Differences in } \\
\text { registry on } \\
\text { accounts }\end{array}$ & ease of determination to certain accounts in accounting \\
\hline $\begin{array}{l}\text { Documentary } \\
\text { confirmation }\end{array}$ & $\begin{array}{l}\text { costs were recorded in primary documents (work } \\
\text { completion certificate, act of delivery and acceptance) }\end{array}$ & $\begin{array}{l}\text { difficulty of determining accounts to } \\
\text { which costs should be included } \\
\text { recorded (in some cases checks are } \\
\text { used) }\end{array}$ \\
\hline $\begin{array}{l}\text { Examples } \\
\text { programs for economic security system effectiveness, } \\
\text { social events, depreciated cost, personnel training costs } \\
\text { funds for ensuring confidentiality of information; making } \\
\text { external users: counterparties, suppliers, } \\
\text { competitors }\end{array}$
\end{tabular}

At the present stage of business development and cooperation with international partners, the issue of enterprise economic security transaction costs accounting, being paid a special attention to, is increasingly raising. Considering economic security transaction costs, we find out the following interpretations:

- costs considered as costs of agent's behaviour monitoring and his self-restraint [11];

- costs of collecting and processing information, costs of contract performance controlling and legal protection [12];

- time consumption and other valuable resources of the enterprise for various contacts with its external environment, as well as internal communications: contacts with tax and other state bodies, communicating with its customers, suppliers, partners, etc.

- costs of finding counterparties, determining sales price and volume for each transaction, and providing redistribution of property rights [13].

First of all, it is difficult to reflect economic security costs on accounts of accounting.
To summarize these costs, we suggest presenting them in a separate complex Article 92.nb "Enterprise economic security costs" as part of administrative expenses. After all, these costs fully coincide with nature of the administrative costs, because they are aimed at supporting the main activities of the enterprise, are permanent and anyway are not associated with volume of output.

Additionally to the suggested account, it is of paramount importance to open the following analytical accounts:

a - costs of establishing economic security system;

$\mathrm{b}-$ costs of maintaining economic security service staff;

c - costs of creating economic security database;

d - other costs associated with activities of economic security service.

Typical correspondence of accounts from economic security costs accounting are presented in Table 2. 


\section{Correspondence of accounts from enterprise economic security costs accounting *}

\begin{tabular}{|c|c|c|c|c|}
\hline \multirow[t]{2}{*}{ № } & \multirow[t]{2}{*}{ Contents of business operations } & \multicolumn{2}{|c|}{$\begin{array}{l}\text { Correspondence of } \\
\text { accounts }\end{array}$} & \multirow[t]{2}{*}{ Initial documents } \\
\hline & & Debit & Credit & \\
\hline 1 & 2 & 3 & 4 & 5 \\
\hline \multicolumn{5}{|c|}{ Costs of establishing economic security system } \\
\hline 1 & Personnel searching costs & $92 . n a$ & 661 & Work completion certificate \\
\hline 2 & A single social contribution has been calculated & 92.na & 651 & $\begin{array}{l}\text { Summary statement of deductions } \\
\text { to the Funds }\end{array}$ \\
\hline 3 & Premises searching costs & $92 . n a$ & 685 & Work completion certificate \\
\hline \multirow[t]{2}{*}{4} & \multirow{2}{*}{$\begin{array}{l}\text { Costs of equipment, computers, that will be } \\
\text { used by enterprise security service }\end{array}$} & $\begin{array}{l}152 \\
104\end{array}$ & 631 & \multirow{2}{*}{$\begin{array}{l}\text { Act of delivery and acceptance, } \\
\text { Work completion certificate }\end{array}$} \\
\hline & & $92 . n a$ & 131 & \\
\hline 5 & $\begin{array}{l}\text { Costs of an outside organization involved in } \\
\text { establishing economic security service }\end{array}$ & 92.na & 685 & Work completion certificate \\
\hline 6 & $\begin{array}{l}\text { Other costs associated with establishing } \\
\text { enterprise economic security service }\end{array}$ & 92.na & $\begin{array}{l}20,22 \\
372\end{array}$ & $\begin{array}{l}\text { Work completion certificate, } \\
\text { Checks, Accounting certificate }\end{array}$ \\
\hline \multicolumn{5}{|c|}{ Costs of maintaining economic security service staff } \\
\hline 1 & $\begin{array}{l}\text { Calculating the basic and additional salaries of } \\
\text { the staff }\end{array}$ & $92 . n b$ & 661 & $\begin{array}{l}\text { Working hours record sheet, } \\
\text { After-payment sheets }\end{array}$ \\
\hline 2 & Calculating a single social contribution & $92 . n b$ & 651 & $\begin{array}{l}\text { Summary statement of deductions } \\
\text { to the Funds }\end{array}$ \\
\hline 3 & $\begin{array}{l}\text { Calculating depreciation of technical means for } \\
\text { ensuring economic and staff security }\end{array}$ & $92 . n b$ & 131 & $\begin{array}{c}\text { Statement of charging fixed assets } \\
\text { depreciation }\end{array}$ \\
\hline 4 & $\begin{array}{l}\text { Reflecting costs associated with advisory } \\
\text { recommendations for personnel's skills }\end{array}$ & $92 . n b$ & 685 & Work completion certificate \\
\hline 5 & $\begin{array}{l}\text { Reflecting costs of exchanging experience in the } \\
\text { field of economic security }\end{array}$ & $92 . n b$ & 372 & $\begin{array}{l}\text { Certificates confirming speciality } \\
\text { and obtained skills }\end{array}$ \\
\hline 6 & $\begin{array}{l}\text { Reflecting costs of staff training for improving } \\
\text { their skills }\end{array}$ & $92 . n b$ & 685 & Work completion certificate \\
\hline 7 & $\begin{array}{l}\text { Costs of maintaining public transport vehicles } \\
\text { for security service activities }\end{array}$ & $92 . n b$ & 205,131 & $\begin{array}{l}\text { Checks, Work completion } \\
\text { certificate, Travel itinerary form }\end{array}$ \\
\hline \multicolumn{5}{|c|}{ Costs of creating economic security database } \\
\hline 1 & $\begin{array}{l}\text { Depreciation deductions for software used by } \\
\text { the service }\end{array}$ & $92 . n c$ & 133 & $\begin{array}{l}\text { Statement of charging intangible } \\
\text { assets depreciation }\end{array}$ \\
\hline 2 & $\begin{array}{l}\text { Costs of purchasing special literature used in } \\
\text { employees' practical work }\end{array}$ & $92 . n c$ & $\begin{array}{l}109,11 \\
127\end{array}$ & Act of delivery and acceptance \\
\hline 3 & $\begin{array}{l}\text { Depreciated costs of books, office literature, and } \\
\text { literature used by the service }\end{array}$ & $92 . n c$ & 133,131 & $\begin{array}{l}\text { Statement of charging intangible } \\
\text { assets depreciation }\end{array}$ \\
\hline 4 & Internet services costs & $92 . n c$ & 685 & Work completion certificate \\
\hline 5 & The cost of software maintenance services & $92 . n c$ & 631 & Work completion certificate \\
\hline
\end{tabular}


Continuation of table 2

\begin{tabular}{|c|c|c|c|c|}
\hline 1 & 2 & 3 & 4 & 5 \\
\hline 6 & $\begin{array}{l}\text { Other costs associated with the activities } \\
\text { of information security staff }\end{array}$ & $92 . n c$ & $\begin{array}{c}661 \\
651 \\
91\end{array}$ & $\begin{array}{l}\text { Accounting certificate, Working hours record } \\
\text { sheet, After-payment sheets, Summary statement } \\
\text { of deductions of Single premium insurance }\end{array}$ \\
\hline \multicolumn{5}{|c|}{ Other costs associated with activities of economic security service } \\
\hline 1. & $\begin{array}{l}\text { Costs of engaging the services of } \\
\text { auditors, audit firms, lawyers, } \\
\text { controllers, experts }\end{array}$ & 92.nd & $\begin{array}{c}685, \\
66, \\
65, \\
683\end{array}$ & $\begin{array}{l}\text { Work completion certificate, Working hours } \\
\text { record sheet, Summary statement of deductions } \\
\text { of Single premium insurance }\end{array}$ \\
\hline 2. & Representative costs & 92.nd & $\begin{array}{l}372 \\
66,65\end{array}$ & $\begin{array}{c}\text { Calculation of representative costs, responsible } \\
\text { person's report }\end{array}$ \\
\hline 3. & $\begin{array}{l}\text { Services of external auditors in external } \\
\text { environment monitoring and verification } \\
\text { of counterparties reliability }\end{array}$ & 92.nd & $\begin{array}{c}685 \\
631\end{array}$ & $\begin{array}{l}\text { Work completion certificate, service notes on } \\
\text { cost efficiency }\end{array}$ \\
\hline 4. & $\begin{array}{l}\text { Payment for the services of } \\
\text { representatives of the public authorities }\end{array}$ & 92.nd & 683 & Service notes on cost efficiency \\
\hline 5. & Cost of purchasing stationery, containers & 92.nd & 22 & $\begin{array}{l}\text { Act of delivery and acceptance, Write-off } \\
\text { certificate }\end{array}$ \\
\hline 6. & Cost of keeping information confidential & 92.nd & $\begin{array}{l}685 \\
683 \\
\end{array}$ & Service notes, Accounting certificate \\
\hline 7. & $\begin{array}{l}\text { Cost of utilities used for maintening } \\
\text { security services }\end{array}$ & 92.nd & 685 & Accounts \\
\hline
\end{tabular}

*Sources: $[2,7,9,10]$

\section{Reflecting economic security costs in the enterprise management reporting}

In accounting, documentary confirmation is a basis for recognizing transactions related to economic security costs. It is worth creating a mechanism for costs documentary regulation, as they are a source of enterprise's economic benefits. This mechanism shall provide the procedure for determining and spending economic security costs using documentary confirmation. It shall be fixed in the administrative documents of the enterprise, such as: manager's orders or instructions. Such documents shall include number of responsible persons involved in performing economic security service objectives, the purpose and expediency of carrying out its activities, etc.

The formation of cost estimate is a special element of accounting, because not all economic security costs can be documented (negotiation costs, counterparty audits). This cost estimate is calculated on the basis of approved allowable amounts of costs in the section of enterprise economic security. It consists of establishing responsible persons for the actual write-off. Documentary confirmation is the following:

- Statement of actual costs incurred, indicating the date of actual write-off, as well as the measures related to it;

- Costs incurred certificate is an internal document confirming the financial security work performed and the amount of cash incurred, and also including a date and a responsible person;

- Accounting note is a document that records the date of measures with the specified amounts and correspondence of the transaction accounts.

Developing internal management reporting forms, such as "Consolidated statement of 
enterprise economic security costs accounting" and "Statement of analytical accounting of enterprise economic security costs" is justified. A more detailed study of cost deviations from the planned or allowable amounts in terms of economic security costs will give "Control statement of economic security costs by articles".

For management accounting at the enterprise it is necessary to develop a plan of carrying out measures (control, checking) for economic security with indicating terms, the subject of these measures, as well as responsible persons.

Keeping the suggested forms of accounting registers will create an environment of complete information for carrying out analysis of enterprise economic security costs.

\section{Controlling economic security costs}

Control is one of the functions ensuring enterprise economic security. At all stages of the enterprise activities, the main issue is cost, which in turn requires constant improvement and organization of its control.

Since, economic security of an enterprise is defined in [2] as a set of measures that facilitate improving enterprise financial stability, we come into the conclusion that controlling economic security costs is a mechanism for preservation and multiplying resources that provide enterprise financial stability.

The system of internal control of economic security costs provides distinguishing the following organizational and methodological components: style and basic principles of control, organizational structure of the enterprise, interconnection among departments, distribution of powers among employees, and the procedure for reporting (financial, tax, statistical), its accessibility to users, availability of control services at the enterprise (audit committee, internal audit, economic security service) [7].

Internal control is an element of the enterprise economic security, which makes it possible to verify the expediency, efficiency or legitimacy of its business operations.

An efficient functioning of control in the system of enterprise economic security is achieved with following the basic principles - specific rules applying to all types of control activities of the enterprise:

- responsibility (indicating that each employee of the enterprise economic security service for the improper performance of his official duties (control functions) must bear administrative and disciplinary responsibility);

- timeliness (obliges each control procedure executant to inform about his activities including risks and deviations in time, because in case the information is not submitted to a higher level of control in time, the deviation consequences can increase. Because of this an object gets another meaning of investigation in this direction that will cause meaningless of conducting control);

- complexity (efficiency will not be achieved when control attention is focused only on a relatively narrow range of objects);

- staff skills (involving subordinates in the formation of goals and providing training and retraining for increasing their skills level);

- integration (causes considering control in correlation with other elements in a single management process. When solving specific tasks related to control, it is necessary to create appropriate conditions for closer cooperation of employees from different functional areas);

- sharing responsibilities and duties (duties and responsibilities should be shared in such a way that no employee bears responsibility for the task as a whole. The functions should be shared between several employees in order to avoid abuse and for efficient control).

Using control in the enterprise economic security costs management, a set of measures is carried out in the interest of protecting business activities against internal and external negative economic risks [8]. In turn, it allows the enterprise to:

- ensure sustainable economic development;

- achieve strengthening of the control system by forming effective accounting of financial flows;

- develop and implement a system of continuous monitoring of deviations from the planned indicators of business activities results.

The enterprise control environment affects the economic security and its business activities efficiency. There are organizational and 
methodological components of the control environment, such as : organizational structure of the economic entity; sharing responsibilities and powers; procedure for preparation of financial statements; existence and peculiarities of organizing work of enterprise economic security service, audit committee, internal audit service.

\section{Conclusions}

Enterprise economic security is a degree of its protection against external and internal factors that allows stable activities and sustainable development and mostly depends on a wellorganized management system. The functioning of economic security system is accompanied by many problems, a partial solution of which is possible due to the use of a suggested subaccount "Economic security costs" in the accounting. This will facilitate finding necessary data and using information to manage economic security costs. In addition, we suggest different forms of internal management accounting registers, which using will allow accumulating information on enterprise economic security costs for conducting analysis and control in this area.

The results of the conducted research show that under current management conditions, a correct estimation of enterprise financial activity is necessary not only to owners and management, but also to state bodies and competitors. The latter is mostly interested in the negative aspects of the financial situation, because they focus on weakening competitors' positions in the market. To prevent this, it is necessary to conduct control measures directly during enterprise activities, as well as to take measures to ensure enterprise economic security in time. Controlling of enterprise economic security costs is not solely the prerogative of any one department, service, or group of individuals. It must be maintained and followed by the whole internal structure of the entity.

\section{Prospects for further research}

The further research works can be devoted to making revision and suggesting advanced approaches to analysing enterprise economic security costs. The organization of accounting and forming documentation of enterprise economic security costs affects control quality. Not only methods and measures of control but also its goals, directions and objectives require further improvement and specification. The prospects of further scientific investigations are also improving of analytical control procedures, formation of measures for implementing control results and developing particular methodological decisions.

\section{References}

1. Liashenko, O. M. (2015). Kontseptualizatsiia upravlinnia ekonomichnoiu bezpekoiu pidpryiemstva [The conceptualization of economically secure enterprise management]. Retrieved from http://old2.niss.gov.ua/content/articles/files/ lyashenko_1_druk-43fc7.pdf [in Ukrainian].

2. Shtanhret, A. M. \& Karaim, M. M. (2017). Kontseptualni zasady formuvannia systemy oblikovoanalitychne zabezpechennia upravlinnia ekonomichnoiu bezpekoiu pidpryiemstva [Conceptual bases of formation of accounting and analytical support system for management of company's economic security]. Lviv: Naukovi zapysky Ukrainskoi akademii drukarstva, 1(54), 147-153 [in Ukrainian].

3. Bartashevska, Yu.M. (2016). Ekonomichna bezpeka pidpryiemstva: faktory vplyvu ta shliakhy zabezpechennia [Economic security of the enterprise: factors of influence and ways of providing]. Mukachiv: Ekonomika i suspilstvo. Mukachivskyi Derzhavnyi Universytet, 7, 189-194. Retrieved from http://www.economyandsociety. in.ua/journal/7_ukr/32.pdf [in Ukrainian].

4. Oleksiv, I. (2014). Theoretical and practical approaches to identification of stakeholder interests of the company. Lviv: Economics, Entrepreneurship, Management. Lviv Polytechnic National University. 1 (1), 31-35

5. Qi, Z., Shi, Z., Li, F., Zhang, H., Liu, H. \& Feng J. (2016). Development and application of the security stability control management system. Power System Protection and Control. 44 (1), 122-127.

6. Ovcharuk, V. V. (2018). Systemy administruvannia $v$ upravlinni pidpryiemstvamy: pobudova ta zastosuvannia z urakhuvanniam yevrointehratsiinykh protsesiv [Administration systems in enterprise management: construction and application taking into account European integration processes]. Lviv: Halytska vydavnycha spilka, 276 [in Ukrainian].

7. Pogorelov, Y. S. \& Bulcot H. V. (2014). Pryntsypy ta skladovi kontroliu yak elementu systemy ekonomichnoi bezpeky pidpryiemstva [Principles and components of control as an element in an enterprise economic security system]. Khmelnitsky: 
Accounting and analytical support for formation of enterprise economic security costs and their...

Visnyk Khmelnytskoho natsionalnoho universytetu. Ekonomichni nauky, 3, 39-41. [in Ukrainian].

8. Kostyrko, R. O. (2010). Kontrol $i$ analiz $v$ systemi upravlinnia ekonomichnym potentsialom hospodariuiuchoho sub'iekta: metodolohiia ta orhanizatsiia [Control and analysis in the economic potential management system of an economic entity: methodology and organization.]. Luhansk: Skhidnoukrainskyi universytet im. V. Dalia [in Ukrainian].

9. Hnylytska, L. (2014). Vidobrazhennia vytrat, pov'iazanykh $z$ diialnistiu iz zabezpechennia bezpeky pidpryiemstva $v$ systemi bukhhalterskoho obliku ta vidkrytoi zvitnosti [Display costs related to enterprise security activities in accounting and open reporting]. Bukhhalterskyi oblik i audyt. 4, 39-46 [in Ukrainian]

10. Vytraty [Costs]. (1999, December 14). Polozhennia (standart) bukhhalterskoho obliku N16. Nakaz Ministerstva finansiv Ukrainy [National accounting principles (standard) (NAP(S)) Order of the Ministry of Finance of Ukraine ] № 860/4153. Retrieved from https://zakon.rada.gov.ua/laws/ show/z0027-00 [in Ukrainian]

11. Zhyvko Z.B. (2012) Ekonomichna bezpeka pidpryiemstva: sutnist, mekhanizm zabezpechennia ta upravlinnia [Economic security of the enterprise: essence, mechanism of providing and management] Lviv. LihaPres, 256 [in Ukrainian]

12. Shatalkin, I. A. (2014) Problemyi izmereniya transaktsionnyih izderjeki sposobyi ih preodoleniya [Problems of transaction costs' measurement] Scientists notes of Petrozavsk State University. 1, 108-110. [in Russian]

13. Zakharov O. Yu. (2008). Obespechenie kompleksnoy bezopasnosti predprinimatelskoy deyatelnosti. Teoriya $i$ praktika [Ensuring comprehensive security of business activity. Theory and Practice] Moscow: VCT, 320 [in Russian] 